кандидат історичних наук, доцент,

Київський національний економічний університет ім. Вадима Гетьмана,

Київ, Украӥна;

Чалюк Юлія Олексї̈вна

кандидат економічних наук, доиент,

Київський національний економічний університет ім. Вадима Гетьмана,

Київ, Украӥна,

Lamur4ik@bigmir.net

\title{
КОНЦЕПЦІЯ ГЛОБАЛЬНОЇ ОСВІТИ В ІСТОРИЧНІЙ РЕТРОСПЕКТИВІ
}

У статті в історичній ретроспективі досліджено теоретичні й прикладні аспекти концепції глобальної освіти. На основі аналітичного й емпіричного матеріалу обгрунтовано необхідність в умовах глобальної економіки та міжнародної комунікації транснаціонального навчання i перетворення провідних університетів світу на міжнародні науково-освітні комплекси. Здійснено ідентифікацію нових освітніх стратегій ООН, ЮНЕСКО, а також інноваційних форм і методів інтеграції країн СС у міжнародний освітній простір, зокрема акредитованих і валідованих програм, франчайзингових програм, програм подвійних і спільних дипломів із застосуванням електронного навчання та дистанційних технологій. Застосування методів структурно-системного аналізу дало можливість визначити основні канали міжнародного обміну освітніми послугами, серед яких важливо виділити транскордонне постачання, споживання за кордоном, комерційну присутність і надання послуги фізичною особою. Проаналізовано основні механізми, ефективність та якість надання міжнародних освітніх послуг.

Ключові слова: асоційовані школи, Європейський освітній простір, інноваційні освітні стратегії, концепція глобальної освіти, міжнародні освітні послуги, транснаціональне навчання, ЮНЕСКО.

Dovhanyl Nadiia, Candidate of Historical Sciences, Associate Professor, Kyiv National Economics University named after Vadym Hetman, Kyiv, Ukraine;

Chaliuk Yuliia, Candidate of Economics, Associate Professor, Kyiv National Economics University named after Vadym Hetman, Kyiv, Ukraine

\section{Concept of global education in historical retrospective}

The article explores the historical retrospective, theoretical, and applied aspects of the concept of global education. The necessity for a global economy and international communications transnational learning and transformation of leading universities at international scientific and educational complexes were justified on the basis of analytical and empirical material. It was identified of new educational policies of the UN, UNESCO and innovative forms and methods of integration of the EU in international educational space: accredited and validated programs franchised programs, dual and joint degrees with the use of E-learning and distance learning technologies. Application of methods structural and system analysis enabled to identify the main channels of international exchange of educational services, among which important allocate the cross-border supply, consumption abroad, commercial presence and providing services by individuals. It analyzes the main mechanisms, efficiency and quality of international education.

Key words: associated schools, European educational space, innovative educational strategies, the concept of global education, international education services, transnational education, UNESCO. 
Довганик Надежда Михайловна, кандидат исторических наук, доцент, Киевский наииональный экономический университет им. Вадима Гетьмана, Киев, Украина;

Чалюк Юлия Алексеевна, кандидат экономических наук, доиент, Киевский начиональный экономический университет им. Вадима Гетьмана, Киев, Украина

\section{Концепция глобального образования в исторической ретроспективе}

В статье в исторической ретроспективе исследованы теоретические и прикладные аспекты концепции глобального образования. На основе аналитического и эмпирического материала обоснована необходимость транснационального обучения и преобразования ведущих университетов мира на международные научно-образовательные комплексы в условиях глобальной экономики и международной коммуникации. Осуществлена идентификация новых образовательных стратегий ООН, ЮНЕСКО, а также инновационных форм и методов интеграции стран ЕС в международное образовательное пространство, в частности аккредитованных и валидизированных программ, франчайзинговых программ, программ двойных и совместных дипломов с применением электронного обучения и дистанционных технологий. Применение методов структурно-системного анализа позволило определить основные каналы международного обмена образовательными услугами, среди которых важно выделить трансграничную поставку, потребление за рубежом, коммерческое присутствие и предоставление услуги физическим лицом. Проанализированы основные механизмы, эффективность и качество предоставления международных образовательных услуг.

Ключевые слова: ассоциированные школы, Европейское образовательное пространство, инновационные образовательные стратегии, концепция глобального образования, международные образовательные услуги, транснациональное обучение, ЮНЕСКО.

Вступ. Одним із варіантів відповіді на глобальні соціальні виклики сучасності є концепція глобальної освіт, у 70-ті pp. XX ст. американським ученим Р. Хенві, у подальшому конкретизована у документах наднаціональних організацій (ООН, ЮНЕСКО, СС та ін.) і адаптована у практиці міжнародних освітніх установ. Під егідою ЮНЕСКО було утворено інноваційні школи, що отримали статус Асоційованих шкіл ЮНЕСКО, мережа системи яких об'єднує нині приблизно 8500 шкіл та ін. учбові заклади у 178 країнах світу. Асоційовані школи ЮНЕСКО найбільш повно реалізують світоглядні позиції наднаціональних організацій $\mathrm{OOH}$ і $\mathrm{CC}$, охоплюючи чотири пріоритетні напрями: права людини, екологічну освіту, збереження культурної спадщини та дисемінацію діяльності ООН.

Аналіз попередніх публікацій та формулювання мети дослідження. Незважаючи на зростаючу кількість наукових публікацій, окремі історико-теоретичні та практичні аспекти концепції глобальної освіти $є$ недостатньо дослідженими. Поглибленого аналізу потребує, насамперед, подальша іiі конкретизація та розвиток у міжнародних документах. Принципово важливою $\epsilon$ також проблема реалізації даної концепції у практичній діяльності таких наднаціональних організацій як ООН, ЮНЕСКО, ЄС. Це зумовлює актуальність і наукову значимість обраної теми, метою якої $є$ наукове дослідження в історичній ретроспективі теоретичних і прикладних аспектів концепції глобальної освіти.

Виклад матеріалу дослідження. Як міжнародна спеціалізована Організація Об'єднаних Націй з питань освіти, науки й культури (ЮНЕСКО) була створена у 1945 р. і об'єднує нині 195 постійних і 9 асоційованих країн-членів. Перед собою вона ставить завдання сприяти зміцненню миру й безпеки шляхом розширення співробітництва народів у галузі освіти, науки й культури в інтересах забезпечення загальної поваги до справедливості, законності, прав людини і основних свобод, проголошених у Статуті ООН для всіх народів без розрізнення раси, статі, мови чи релігії. Цей політичний імператив був закріплений і розширений у Декларації принципів міжнародного культурного співробітництва ЮНЕСКО [6]. 
Наступним історичним кроком у розвитку міжнародної складової програмних документів ЮНЕСКО слід вважати Рекомендацію про виховання у дусі міжнародного взаєморозуміння, співробітництва і миру та поваги прав людини і основних свобод (1974), що вводить у науковий обіг нове поняття «міжнародне виховання», у якому поєднуються терміни - міжнародне взаєморозуміння, співробітництво і мир між народами та державами, що мають різні соціальноекономічні й політичні системи.

Разом із іншими партнерами ЮНЕСКО очолила наймасштабнішу кампанію 3 досягнення загальної і високоякісної початкової освіти до 2020 р. на основі «Рамок дій», прийнятих 181 країною у 2000 р. на Всесвітньому форумі з освіти у Дакарі (Сенегал). У вересні 2000 р. ця ціль була підтверджена світовими лідерами в Декларації тисячоліття. Форум здійснив найбільш точний за всю історію статистичний аналіз освіти, який охопив дворічний період «Оцінки загальної освіти» $\mathrm{i}$ регіональних конференцій високого рівня 1999-2000 pp.

Середньострокова стратегія 2014-2021 рр. відводить ЮНЕСКО роль лідера у визначенні Цілей стійкого розвитку, що прийдуть на зміну Цілям розвитку тисячоліття, у таких галузях як освіта, наука, культура і комунікація. Безграмотними залишаються у світі 781 млн. дорослих, половина 3 яких проживає на Африканському континенті. Не вміють читати й писати 126 млн. дітей, $60 \% 3$ них - це дівчатка. Тому закономірним є визначення двох глобальних пріоритетів - Африка і гендерна рівність [6, с. 12-15].

Бюджет ЮНЕСКО 2014-2017 pp. у сумі 653 млн дол. був скорочений на 146 млн. дол. [6, с. 21-25]. В умовах бюджетного дефіциту активізувалося співробітництво ЮНЕСКО 3 міжнародними фінансовими установами, приватним сектором, країнами-донорами. Набувають особливого значення такі форми партнерства як галузева співпраця, використання міжнародних мереж і засобів масової інформації, співробітництво 3 міжнародними міжурядовими та міжнародними неурядовими організаціями, у тому числі у рамках співпраці Південь-Південь та трикутникового співробітництва ІБСА (Індія, Бразилія, Південна Африка).

Партнерські відносини між ЮНЕСКО і Світовим банком знайшли своє відображення у стратегії на період до 2020 р. «Якісна освіта для всіх». Значні інвестиції (750 млн. дол.) у здійснення проекту забезпечує СБ. У центрі уваги стратегії знаходяться країни Африки на південь від Сахари [4, с. 158-170].

Крім традиційних міжнародних систем оцінювання процесу навчання, таких як Міжнародна програма оцінки освітніх досягнень учнів (PISA) і дослідження «Міжнародні тенденції у розвитку математики та природничих наук» (TIMSS), ЮНЕСКО активно використовує у своій роботі інноваційні механізми - міжнародний інструментарій BOOST, за допомогою якого здійснюється контроль за використанням бюджетних коштів у сфері освіти, а також комплекс програм системних оцінок і аналізу опорних показників у галузі освіти (SABER): «Політика по відношенню до вчителів», «Оцінка освітніх досягнень учнів», «Розвиток дітей у ранньому віці» і «Розвиток трудових ресурсів».

До новітніх інструментів, що користуються попитом у країнах, які у сфері освіти значно відстають, належать стипендії для дівчат, програми умовних грошових трансфертів, а також шкільні гранти. Названі ініціативи ЮНЕСКО та СБ сприяють підвищенню відвідування шкіл дітьми із соціально неблагополучних сімей і забезпечують широке охоплення дітей шкільною освітою [6, с. 10].

Сектор вищої освіти ЮНЕСКО об'єднує 854 кафедри та 67 мереж Організації, які працюють у 134 країнах над питаннями наукових досліджень, підготовки кадрів і міжнародного співробітництва. У рамках сектору діють також 6 спеціалізованих інститутів та 2 центри: [6, с. 12]. У сфері науки і технології ЮНЕСКО займається розробкою етичних принципів, стандартів і правових актів. Нею була прийнята у 1952 р. Всесвітня конвенція про авторське право (переглянута у 1971 р.). 
Проблемами регулювання інтелектуальної власності у міжнародному аспекті в основному займаються створена у 1967 р. Всесвітня організація інтелектуальної власності (ВОIВ) і заснована у 1994 р. Світова організація торгівлі (СОТ).

Регулювання глобального ринку освітній послуг неможливе без Генеральної угоди 3 торгівлі послугами (ГАТС). Торгівля послугами у міжнародному масштабі не завжди передбачає перетин послугою національних кордонів. ГАТС визначає чотири канали міжнародного обміну послугами: транскордонну поставку, споживання за кордоном, комерційну присутність і надання послуги фізичною особою. Згідно ГАТС торгівля освітніми послугами, наприклад, може здійснюватися за допомогою таких чотирьох способів. Перший передбачає транскордонну поставку освітніх послуг, коли споживачі (студенти) залишаються у межах країни, а продаж послуги відбувається через канали зв'язку - телефон, Інтернет (дистанційна освіта). Другий спосіб допускає споживання послуги за кордоном у країні-експортері. Третій вимагає комерційної присутності постачальника у країні, що споживає послугу, через відкриття університету, філії, відділення, представництва. Четвертий пов'язаний із наданням послуг фізичною особою (викладання англійської мови носіями з Канади, США чи Великої Британії за межами своїх держав). ГАТС доповнює ГАТТ у торгівлі послугами і тим самим разом з ТРІПС є необхідним етапом на шляху уніфікації всієї системи багатостороннього регулювання міжнародних соціальноекономічних відносин [2, с. 120-122].

Показники грамотності дорослого населення - на рівні $100 \%$ та середньої тривалості навчання - не менше 15 років свідчать про високий освітній статус населення європейських країн, що в свою чергу визначає конкурентоспроможність людських ресурсів. Практично кожна доросла людина здобуває сучасну професійну освіту, кошти на отримання якої виділяє держава та бізнес. Атмосфера соціальної конкуренції стимулює людей до навчання упродовж усього життя (lifelong learning), професійної і географічної мобільності, самореалізації як вищої суспільної цінності [3].

У числі своїх пріоритетів Європейський Союз висунув завдання створення Європейського простору вищої освіти (СПВО) поряд з єдиним освітнім простором (European research area - ERA). Практичне створення ERA почалося 3 реалізації Шостої Рамкової програми 2002-2006 pр. Виходячи 3 вимог якої, всі напрями досліджень були підпорядковані головному завданню об'єднання європейської науки, а методи виконання розроблені з метою надання максимальної підтримки бізнесу, академічним колам, науково-дослідним інститутам, а також усунення перешкод, що обмежують мобільність учених країн ЄС. Формування єдиного Європейського освітнього простору здійснюється в рамках Болонського процесу. Нині учасниками Болонського процесу і декларації «Зона європейської вищої освіти» є 46 європейських країн, включно з Україною [1].

Європейський Союз є лідером у сфері міжнародних освітніх послуг, витримуючи жорстку конкуренцію з боку США, Австралії та Китаю. У країнах СС навчаються понад 40 \% іноземних студентів. Тенденція до подальшого збільшення їх числа викликана інтеграційними процесами у сфері вищої освіти [4, с. 200-204]. Незважаючи на те, що в державних вузах багатьох країн ЄС (наприклад, Франції та Німеччини) зберігається безкоштовна вища освіта, експорт освітніх послуг стає одним із найважливіших і високоприбуткових статей у структурі загального експорту європейських країн, особливо Великобританії. Орієнтація на експорт і одержані від нього значні фінансові кошти сприяють модернізації системи вищої освіти [3].

Експерти називають принципово важливим положенням Болонської декларації можливість отримання студентами одночасно двох дипломів різних країн (подвійні дипломи). Відповідно до рекомендацій Ради Свропи під спільним дипломом слід розуміти такий, що видається не менш як двома ВНЗ на основі спільної освітньої програми, яка може виконуватися студентом як на території обох сторін угоди про спільний диплом, так і без виїзду в іншу країну [5]. Такі угоди називають ще Договором про мережеву форму реалізації освітніх програм. Для спільної діяльності Болонським процесом передбачені валідовані і франчайзингові програми. Сутність валідованої програми полягає у визнанні одним ВНЗ еквівалентності програм іншого навчального закладу 3 
можливою видачею власного диплома випускникам ВНЗ-партнера. Франчайзингові програми передбачають передачу права реалізації своєї освітньої програми іншому ВНЗ з правом контролю якості навчання. Високим освітнім стандартам відповідають акредитовані програми, які отримали експертну оцінку якості. Можливості одночасного отримання двох і більше дипломів різних країн зростають у ході реалізації освітніх програм із застосуванням електронного навчання i дистанційних технологій [2, с. 96-97].

Висновки. Для реалізації державної політики у сфері експорту послуг на освітньому ринку в країнах $\mathrm{CC}$, по-перше, розробляються цільові загальноосвітні програми з чітко визначеними завданнями і відповідним фінансовим забезпеченням; по-друге, створено державні або недержавні організації, служби сприяння експорту освітніх послуг та академічному обміну викладачів і студентів (наприклад, у Франції - освітнє агентство Edufrance, Великій Британії - Рада міжнародної освіти British Council, Німеччині - служба академічних обмінів Daad).

У стратегічних планах розвитку все більше провідних освітніх закладів $\mathrm{CC}$ орієнтуються на підготовку фахівців в умовах глобальної економіки та міжнародної комунікації, транснаціональне навчання і перетворення на міжнародні науково-освітні комплекси. При цьому країни ЄС використовують різноманітні форми і методи інтеграції в міжнародний освітній простір, зокрема, акредитовані і валідовані програми, франчайзингові програми, програми подвійних і спільних дипломів, створення єдиного освітнього простору.

\section{Список використаних джерел:}

1. Довганик Н. М. Європейська практика оптимізації самоврядності / Н. М. Довганик // Вчені записки. - Київ: КНЕУ, 2007. - Вип. 9. - С. 209-214.

2. Чалюк Ю. О. Міжнародна координація розвитку соціальної сфери: монографія / Ю. О. Чалюк. - Київ: Компринт, 2016. - 270 с.

3. Чалюк Ю. О. Особливості соціальної політики ЄС / Ю. О. Чалюк // Науковий вісник ХДУ. Серія: Економічні науки. - Херсон: Гельветика, 2014. - Вип. 5, ч. 1. - С. 115-118.

4. European social statistics. - Luxemburg: Publications office of the EU, 2013. -242 p.

5. Dovhanyk N. M. International non-governmental organizations and social responsibility /

N. M. Dovhanyk, Y. O. Chaliuk // The scientific heritage - 2017. - Vol. 8 (8), part. 2. - pp. 39-41.

6. Medium - Term Strategy 37 C/4 2014-2021. - Paris: Published by the UNESCO, 2014. - 33 p.

\section{References:}

1. Dovhanyk, N. M. (2007). European practice of self-government optimization. Vcheni zapysky [Scientists note], issue 9, pp. 209-214.

2. Chaliuk, Yu. O. (2016). International coordination of social sphere development: monography. Kyiv: Comprint.

3. Chaliuk, Yu. O. (2014). Features of social policy in the EU. Naukovyi visnyk Khersonskogo derzhavnogo universytetu. Seriya "Ekonomichni nauky» [Scientific Bulletin of Kherson State University. Series "Economic Sciences"], issue 5, part 1, pp. 115-118.

4. The EU. (2013). European social statistics - 2013 edition. Luxemburg: Publications office of the EU.

5. Dovhanyk, N. M., Chaliuk, Y. O. (2017). International non-governmental organizations and social responsibility. The scientific heritage, Vol. 8 (8), Part 2, pp. 39-41.

6. The UNESCO. (2014). Medium - Term Strategy 37 C/4 2014-2021. Paris: Published by the UNESCO.

(C) Довганик Н. М., Чалюк Ю. О., 2018 